\title{
Leaf sampling in carambola trees
}

Renato de Mello Prado*, William Natale

Department of Soils and Fertilizers, FCAV/Unesp, 14884-900, Jaboticabal, rmprado@fcav.unesp.br natale@fcav.unesp.br São Paulo, Brazil

\section{Leaf sampling in carambola trees.}

Abstract - Introduction. The lack of information in the literature regarding the most adequate sampling time and leaf for the assessment of the nutritional status of carambola trees limits the use of leaf analysis as a diagnostic method for this species. Therefore, we determined seasonal variations in the leaf mineral composition of carambola trees cultivated on acid soil and submitted to lime application in order to define criteria for the indication of the diagnostic leaf and the adequate sampling time. Materials and methods. The experiment was set up in a typic Hapludox in Bebedouro, São Paulo, Brazil, with lime doses of $(0,1.85,3.79,5.56$ and 7.41$) \mathrm{t} \cdot \mathrm{ha}^{-1}$ applied in August 1999. Grafted carambola tree seedlings (cv. Malaysia) were planted in December 1999. To assess the nutritional status of the plants, the leaf's macro- and micronutrient concentrations were determined in the third and sixth leaves, including the petiole, in flowering branches without fruits located in the middle third of the plant. Samples were collected throughout 2002, except for January and February due to the lack of flowers. Results and discussion. The results showed that the sixth leaf was more effective than the third leaf for the assessment of the nutritional status of carambola trees, with better differentiation of the lime effect on the levels of $\mathrm{Ca}$, $\mathrm{Mg}, \mathrm{Mn}, \mathrm{Zn}, \mathrm{Cu}$ and $\mathrm{Fe}$, especially during the sampling period from August to October. Conclusion. In the area concerned with this study, the sixth leaf collected during the flowering peak from August to October appears ready to allow a nutritional diagnosis of carambola trees.

Brazil / Averrboa carambola / nutritional status / diagnosis / methods / leaves / mineral content / sampling

\section{Échantillonnage de feuilles chez le carambolier.}

Résumé - Introduction. Le manque d'informations dans la littérature sur l'époque d'échantillonnage la plus adéquate et la feuille la mieux indiquée pour l'évaluation de l'état nutritionnel du carambolier limite l'utilisation de l'analyse foliaire comme technique de diagnostic pour cette espèce. Dès lors, nous avons étudié les variations saisonnières de la composition minérale de feuilles de caramboliers cultivés sur un sol acide et soumis à l'application de chaux afin d'identifier des critères permettant de choisir les feuilles utilisables pour un diagnostic nutritionnel de l'arbre ainsi que la période apte à cette étude. Matériel et méthodes. L'expérimentation a été installée sur un sol Fersialsol typique à Bebedouro, São Paulo, Brésil, avec des doses de chaux de $(0,1,85,3,79,5,56$ et 7,41$)$ t $\cdot h^{-1}$ appliquées en août 1999 . De jeunes caramboliers greffés (cv. Malaisie) ont été plantés en décembre 1999. Pour évaluer l'état nutritionnel des plants, les concentrations foliaires en micro- et macroéléments ont été déterminées sur les troisième et sixième feuilles, y compris le pétiole, de rameaux en floraison mais sans fruits, localisés dans le tiers moyen de l'arbre. Des échantillons ont été prélevés tout au long de l'année 2002, sauf en janvier et février du fait du manque de fleurs. Résultats et discussion. Les résultats ont montré que la sixième feuille était plus efficace que la troisième pour évaluer l'état nutritionnel des caramboliers ; le chaulage a induit des effets significatifs sur les teneurs en $\mathrm{Ca}, \mathrm{Mg}, \mathrm{Mn}, \mathrm{Zn}, \mathrm{Cu}$ et Fe, et cela surtout sur les prélèvements effectués d'août à octobre. Conclusion. Dans la zone concernée par cette étude, la sixième feuille prélevée pendant le pic de floraison entre août et octobre apparaît apte à permettre un diagnostic nutritionnel du carambolier.

2004, vol. 59, p. 2 (C) 2004 Cirad/EDP Sciences All rights reserved DOI: 10.1051/fruits:2004027

RESUMEN ESPAÑOL, p. 289
Brésil / Averrboa carambola / état nutritionnel / diagnostic / méthode / feuille / teneur en éléments minéraux / échantillonnage 


\section{Introduction}

Carambola (Averrboa carambola L.) is a fruit tree originating from Asia, well adapted to tropical regions. The main areas producing carambola fruits include regions in Malaysia, northern Asia, Singapore, Taiwan, Hawaii, Florida, Brazil, Guyana and China [1]. In Brazil, carambola trees are cultivated in an area located between the tropic of Capricorn and the Equator [2]. In that country, the establishment of fertilization procedures is very important for the expansion of carambola tree production, especially on tropical soils which show low natural fertility [3].

The few studies carried out with carambola trees in Brazil were limited to aspects of the quantity of nutrients present in the fruits. Information about leaf diagnosis in this fruit tree is scarce, a fact representing a matter of concern when aiming at the improvement of the management and efficiency of fertilization practices [4]. Thus, the understanding of nutritional aspects in such a way that they do not become production-limiting factors is fundamental for guaranteeing maximum genetic expression of improved plants.

Leaf chemical analysis is based on the premise that the nutritional status of a plant is represented by the concentration of essential minerals present in leaf tissue. This view has been in existence for more than a century, but it was started to be explored only a few decades ago [5].

The distribution of nutrient minerals in the plant and in each of its parts, even along the leaf, is not homogenous, demonstrating the need for sample standardization [6]. Moreover, if the collected leaf sample does not represent the adequate leaf and is not collected at the correct time and in sufficient numbers, it will not be representative of or correctly reflect the nutritional status of the crop [7]. Thus, these first two factors, i.e., an adequate leaf and correct sampling period, are the most important in the definition of criteria for leaf diagnosis.

There is a general indication for carambola leaf sampling, which suggests sampling of a recently mature leaf on branches without fruits, collecting ten leaves per tree in all quadrants of the plant, with a minimum of ten trees per homogenous field, between
June and July [8]. However, this procedure does not state precisely which type of leaf must be sampled.

The objective of the present study was to propose a diagnostic leaf and the adequate sampling period. Our work aimed at evaluating seasonal variations in the chemical composition of nutrients in leaves located in different positions on the branch of carambola trees cultivated on an acid soil and submitted to lime application.

\section{Materials and methods}

The experiment was carried out at the Bebedouro Experimental Citrus Culture Station, located in Bebedouro, São Paulo, Brazil (lat. $20^{\circ} 53^{\prime} 16^{\prime \prime} \mathrm{S}$, long. $48^{\circ} 28^{\prime} 11^{\prime \prime} \mathrm{W}$, altitude of $601 \mathrm{~m}$ ). According to the Köppen classification, the local climate is of the subtropical Cwa type, with short, moderate and dry winters, and hot and rainy summers, characterizing two distinct seasons. The soil is a sandy typical Hapludox (table I).

A liming experiment was used in order to establish a soil fertility gradient and to evaluate the responses of the plant by collecting leaves throughout the year. The lime doses were calculated for the 0 to $30 \mathrm{~cm}$ layer as follows: $\mathrm{D}_{0}=$ zero lime, $\mathrm{D}_{1}=$ half the dose necessary to increase the $\mathrm{V}$ value to $70 \%$, $\mathrm{D}_{2}=$ dose necessary to increase $\mathrm{V}$ to $70 \%$, $\mathrm{D}_{3}=1.5$ times the dose necessary to increase $\mathrm{V}$ to $70 \%$, and $\mathrm{D}_{4}=$ twice the dose necessary to increase $\mathrm{V}$ to $70 \%$, corresponding to $0,1.85$, 3.79, 5.56 and $7.41 \mathrm{t} \cdot \mathrm{ha}^{-1}$. Lime was applied to and incorporated into the 0 to $30 \mathrm{~cm}$ layer in August 1999. The lime used in the experiment contained $455.5 \mathrm{~g} \mathrm{CaO}$ per $\mathrm{kg}$ and $102.1 \mathrm{~g} \mathrm{MgO}$ per kg.

The experimental plot consisted of five grafted carambola plants (cv. Malaysia), with the three central trees selected for leaf chemical analysis. Spacing was $7 \mathrm{~m}$ between rows and $4.2 \mathrm{~m}$ between trees. The carambola trees were planted on December 12, 1999 and were submitted to irrigation (50 L per day per tree). Twelve months after planting, twelve soil samples per plot were obtained at 0 to $20 \mathrm{~cm}$ depth in the cultivation line and from the area of the fertilization band, for the determination of soil nutrients. 
Table I.

Chemical analysis of the (0 to 20$) \mathrm{cm}$ and (20 to 40 ) $\mathrm{cm}$ soil layers (typical Hapludox soil) before lime application in carambola orchards used for studying leaf sampling of trees.

\begin{tabular}{|c|c|c|c|c|c|c|c|c|c|c|c|}
\hline \multirow{2}{*}{$\begin{array}{l}\text { Layer } \\
(\mathrm{cm})\end{array}$} & \multirow{2}{*}{$\mathrm{pH} \mathrm{CaCl} 2$} & \multirow{2}{*}{$\begin{array}{l}\text { Organic matter } \\
\qquad\left(\mathrm{g} \cdot \mathrm{dm}^{-3}\right)\end{array}$} & \multirow{2}{*}{$\begin{array}{c}\text { P resin } \\
\left(\mathrm{mg} \cdot \mathrm{dm}^{-3}\right)\end{array}$} & \multirow{2}{*}{$\mathrm{K}$} & \multirow[t]{2}{*}{$\mathrm{Ca}$} & \multirow[t]{2}{*}{$\mathrm{Mg}$} & \multirow{2}{*}{$\begin{array}{c}(\mathrm{H}+\mathrm{Al}) \\
\mathrm{mmol}_{\mathrm{c}} \cdot \mathrm{dm}^{-3}\end{array}$} & \multirow[t]{2}{*}{ SB } & \multirow[t]{2}{*}{$\mathrm{T}$} & \multirow[t]{2}{*}{$\mathrm{Al}$} & \multirow{2}{*}{$\begin{array}{c}\text { V value } \\
(\%)\end{array}$} \\
\hline & & & & & & & & & & & \\
\hline 0 to 20 & 4.7 & 18 & 6 & 1.3 & 9 & 4 & 40 & 14.3 & 54.3 & 8 & 26 \\
\hline 21 to 40 & 4.4 & 16 & 3 & 0.8 & 6 & 4 & 41 & 10.8 & 51.8 & 11 & 21 \\
\hline
\end{tabular}

All plants received NPK throughout the year. Basic fertilization consisted of a mixture of $200 \mathrm{~g} \mathrm{P}_{2} \mathrm{O}_{5}, 20 \mathrm{~L}$ organic compost, $1.0 \mathrm{~g} \mathrm{~B}$ and $2.0 \mathrm{~g} \mathrm{Zn}$ per tree. Cover fertilization for the first and second year consisted of (140 and 200) g N and (112 and 150) g $\mathrm{K}_{2} \mathrm{O}$ per tree, respectively. In 2002, to assess the nutritional status of the trees, the macro- and micronutrient concentrations were determined by sampling the third and sixth recently mature leaves, including the petiole (figure 1), on flowering branches without fruits in the middle third of the tree.

The carambola tree has a high flowering capacity, with flowering occurring at 4 months of age in grafted trees, or at 4 to 6 years in trees obtained from seeds. The phases of reproductive development of carambola trees consist of (a) floral differentiation (initiationemergence), (b) panicle growth, (c) flowering (anthesis, anther dehiscence and pollination), and (d) fructification [2]. Carambola leaves are petiolated, pinnate (two to five pairs of folioles), complete, oval or oval/lanceolate, of pale green color when mature [4]. The chosen leaves had been in branches with greater exposition to sunlight because reports on citrus plants have indicated that leaf branches under low luminosity can show lower $\mathrm{N}$ and $\mathrm{P}$ contents [9] and higher $\mathrm{K}$ and Ca contents [10] compared with leaves exposed to adequate luminosity.

Leaves were sampled throughout the year 2002, except for January and February due to the lack of flowers. Ten leaves were collected from each plant in all quadrants in the middle third of the plant, with a total of thirty leaves per treatment for each type of leaf (third or sixth). The concentration of nutrients in plant tissue was determined accord- ing to the methods described by Bataglia et al. [11].

A random block design was used, with five lime doses and four replicates both for the soil and the tree variables. Data were analyzed statistically by analysis of variance and regression analysis, with the linear model showing the best fit. All analyses were carried out using the SAS statistical software [12].

\section{Results and discussion}

Twelve months after planting, soil sampling along the carambola tree line showed a significant and linear increase in $\mathrm{pH}, \mathrm{Ca}$ and

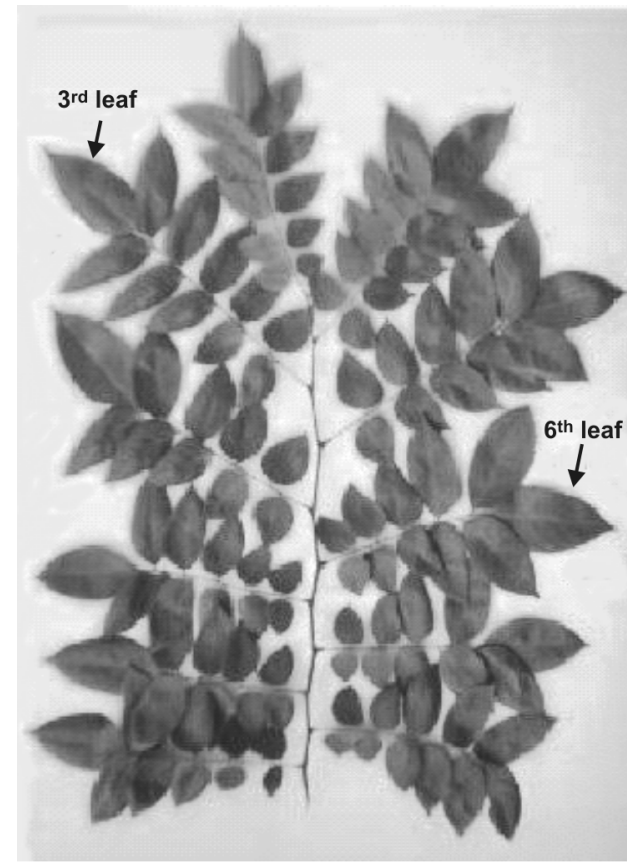

Figure 1.

Branch of carambola tree showing the level of the leaves sampled for studying their chemical composition. 


\begin{tabular}{|c|c|c|c|c|c|c|c|c|c|c|}
\hline \multirow{2}{*}{$\begin{array}{l}\text { Lime dose } \\
\left(\mathrm{t} \cdot \mathrm{ha}^{-1}\right)\end{array}$} & \multirow{2}{*}{$\mathrm{pHCaCl} 2$} & \multirow{2}{*}{$\begin{array}{l}\text { Organic matter } \\
\qquad\left(\mathrm{g} \cdot \mathrm{dm}^{-3}\right)\end{array}$} & \multirow{2}{*}{$\begin{array}{c}\text { P resin } \\
\left(\mathrm{mg} \cdot \mathrm{dm}^{-3}\right)\end{array}$} & $\mathrm{K}$ & $\mathrm{Ca}$ & $\mathrm{Mg}$ & $(\mathrm{H}+\mathrm{Al})$ & SB & $\mathrm{T}$ & \multirow{2}{*}{$\begin{array}{c}\text { V value } \\
(\%)\end{array}$} \\
\hline & & & & \multicolumn{6}{|c|}{$\left(\mathrm{mmol}_{\mathrm{c}} \cdot \mathrm{dm}^{-3}\right)$} & \\
\hline 0 & 4.1 & 19 & 25 & 1.9 & 7 & 3 & 48 & 12.1 & 59.6 & 21 \\
\hline 1,85 & 4.3 & 20 & 28 & 1.9 & 11 & 5 & 43 & 18.2 & 61.4 & 29 \\
\hline 3,79 & 4.4 & 18 & 30 & 1.9 & 11 & 5 & 38 & 18.4 & 55.9 & 33 \\
\hline 5,56 & 4.9 & 19 & 32 & 2.2 & 21 & 11 & 31 & 33.4 & 64.2 & 52 \\
\hline 7,41 & 5.2 & 19 & 25 & 2.0 & 20 & 10 & 26 & 32.0 & 57.7 & 55 \\
\hline Test F & 31.39 ** & $0.21 \mathrm{~ns}$ & $0.43 \mathrm{~ns}$ & $0.51 \mathrm{~ns}$ & $26.02^{\star \star}$ & $29.00^{\star \star}$ & $22.83^{\star \star}$ & $26.22^{* \star}$ & $2.34 \mathrm{~ns}$ & 31.92 ** \\
\hline Reg. linear & 119.62 ** & - & - & - & 89.06 ** & $99.15^{\star *}$ & $90.75^{\star *}$ & $89.37^{\text {** }}$ & - & $119.66^{* \star}$ \\
\hline CV (\%) & 3.5 & 10.9 & 33.0 & 19.0 & 16.9 & 17.7 & 10.1 & 16.1 & 7.0 & 14.0 \\
\hline
\end{tabular}

$\mathrm{Mg}$ content, and a decline in $[\mathrm{H}+\mathrm{Al}]$ content Thus, there was an increase in the sum of bases and in the base saturation of the soil in the 0 to $20 \mathrm{~cm}$ layer (table II). The soil chemical analysis showed a linear increase in soil $\mathrm{pH}$ and, consequently, in the availability of some nutrients. That probably provides favorable conditions for the induction of differences in the nutritional status of the plants. Moreover, base saturation did not reach $70 \%$ because of the buffering power of the soil and of the $\mathrm{pH}$-dependent loads, a fact extensively reported in the literature for tropical soil conditions [13].

The analysis of the effects of the lime dose on nutrient content in carambola leaves at various sampling times showed no significant difference in $\mathrm{N}$ [(19 to 21) $\left.\mathrm{g} \cdot \mathrm{kg}^{-1}\right], \mathrm{P}$ [(0.8 to 1.0$\left.) \mathrm{g} \cdot \mathrm{kg}^{-1}\right]$ or $\mathrm{K}\left[(11\right.$ to 13$\left.) \mathrm{g} \cdot \mathrm{kg}^{-1}\right]$ content between the third and sixth leaves (table III). The lack of alterations in leaf NPK content might be explained by the fact that all plants were fertilized with equal and nonlimiting doses of these nutrients. However, we observed some effects in $\mathrm{Ca}$ and $\mathrm{Mg}$ concentrations and in $\mathrm{Cu}, \mathrm{Fe}, \mathrm{Mn}$ and $\mathrm{Zn}$ concentrations in the leaves (table III). This finding could be explained by the general effects of the liming practice on the chemical properties of soil: an increase in $\mathrm{Ca}$ and $\mathrm{Mg}$ concentration then occurs due to the pres- ence of these elements in the lime. The decrease in the availability in soil of the metal micronutrients $\mathrm{Cu}, \mathrm{Fe}, \mathrm{Mn}$ and $\mathrm{Zn}$ results from insolubilization through the formation of oxides and hydroxides due to an increase in soil pH [14].

Lime application was also found to significantly change $\mathrm{Ca}, \mathrm{Mg}, \mathrm{Cu}, \mathrm{Fe}, \mathrm{Mn}$ and $\mathrm{Zn}$ contents according to sampling time (table III). In this respect, at least two nutrients showed significant alterations for each sampling time, which were always associated with the sixth leaf, except for Fe content (sampling in May 2002) which was only altered in the third leaf (table III). Thus, the effects of lime application on carambola nutrition during the year seem to be better discriminated in samples obtained from the sixth leaf than in those obtained from the third leaf.

Nutrients altered by liming were studied by linear regression in the two types of leaves (third or sixth) in order to obtain the best model, i.e., with a higher coefficient of determination $\left(R^{2}\right)$.

Liming was found to linearly increase $\mathrm{Ca}$ and $\mathrm{Mg}$ leaf concentration, except if $\mathrm{Ca}$ was determined in the third leaf in March 2002 (table IV). For Ca concentration, the coefficients of determination $\left(R^{2}\right)$ were always higher (or practically equal) if the sixth leaf was considered instead of the third leaf. A 
Table III.

Significant F-test values for the leaf concentrations of nutrients in the third and sixth leaves of carambola tree branches during different sampling periods in 2002 as a function of lime application.

\begin{tabular}{|c|c|c|c|c|c|c|c|c|c|c|}
\hline Sampling period & Leaf level & $\mathrm{N}$ & $\mathrm{P}$ & $\mathrm{K}$ & $\mathrm{Ca}$ & $\mathrm{Mg}$ & $\mathrm{Cu}$ & $\mathrm{Fe}$ & $\mathrm{Mn}$ & $\mathrm{Zn}$ \\
\hline \multirow[t]{2}{*}{ March } & 3 & $2.4 \mathrm{~ns}$ & $0.8 \mathrm{~ns}$ & $1.0 \mathrm{~ns}$ & $1.9 \mathrm{~ns}$ & $3.8^{*}$ & $2.2 \mathrm{~ns}$ & $2.9 \mathrm{~ns}$ & $1.1 \mathrm{~ns}$ & $4.4^{*}$ \\
\hline & 6 & $0.8 \mathrm{~ns}$ & $0.5 \mathrm{~ns}$ & $0.8 \mathrm{~ns}$ & $4.1^{*}$ & $4.4^{*}$ & $7.4^{\star \star}$ & $2.1 \mathrm{~ns}$ & $9.9^{\star \star}$ & $15.2^{\text {**}}$ \\
\hline \multirow[t]{2}{*}{ April } & 3 & $1.5 \mathrm{~ns}$ & $1.2 \mathrm{~ns}$ & $1.2 \mathrm{~ns}$ & $4.5^{*}$ & $6.5^{\star *}$ & $3.2 \mathrm{~ns}$ & $1.0 \mathrm{~ns}$ & $15.4^{\star \star}$ & $12.0^{\text {** }}$ \\
\hline & 6 & $0.9 \mathrm{~ns}$ & $2.1 \mathrm{~ns}$ & $1.9 \mathrm{~ns}$ & $3.4^{*}$ & $7.1^{\star \star}$ & $0.3 \mathrm{~ns}$ & $1.1 \mathrm{~ns}$ & $24.4^{\text {**}}$ & $9.8^{* *}$ \\
\hline \multirow[t]{2}{*}{ May } & 3 & $2.1 \mathrm{~ns}$ & $0.6 \mathrm{~ns}$ & $1.2 \mathrm{~ns}$ & $7.2^{\star *}$ & $8.1^{* *}$ & $12.3^{\text {**}}$ & $3.3^{*}$ & $3.6^{*}$ & $3.1 \mathrm{~ns}$ \\
\hline & 6 & $2.0 \mathrm{~ns}$ & $1.4 \mathrm{~ns}$ & $1.5 \mathrm{~ns}$ & $14.5^{\text {** }}$ & $15.5^{* *}$ & $4.3^{*}$ & $1.2 \mathrm{~ns}$ & $5.2 *$ & $6.4^{* *}$ \\
\hline \multirow[t]{2}{*}{ June } & 3 & $1.3 \mathrm{~ns}$ & $0.6 \mathrm{~ns}$ & $1.8 \mathrm{~ns}$ & $5.4^{\star \star}$ & $6.7^{\star \star}$ & $6.1^{\star \star}$ & $0.9 \mathrm{~ns}$ & $4.7^{*}$ & $4.2^{*}$ \\
\hline & 6 & $1.1 \mathrm{~ns}$ & $0.2 \mathrm{~ns}$ & $1.1 \mathrm{~ns}$ & $9.2^{\star \star}$ & $15.5^{\star *}$ & $3.7^{*}$ & $1.3 \mathrm{~ns}$ & $3.3^{*}$ & $4.5^{*}$ \\
\hline \multirow[t]{2}{*}{ July } & 3 & $0.3 \mathrm{~ns}$ & $2.5 \mathrm{~ns}$ & $2.8 \mathrm{~ns}$ & $7.2^{\star *}$ & 4.9 * & $1.8 \mathrm{~ns}$ & $1.1 \mathrm{~ns}$ & $0.2 \mathrm{~ns}$ & $2.1 \mathrm{~ns}$ \\
\hline & 6 & $0.7 \mathrm{~ns}$ & $1.6 \mathrm{~ns}$ & $1.8 \mathrm{~ns}$ & $7.5^{\star *}$ & $9.5^{*}$ & $0.7 \mathrm{~ns}$ & $5.1 *$ & $9.1^{\star *}$ & $4.9^{*}$ \\
\hline \multirow[t]{2}{*}{ August } & 3 & $0.5 \mathrm{~ns}$ & $1.9 \mathrm{~ns}$ & $1.7 \mathrm{~ns}$ & $6.3^{\star \star}$ & $16.1^{\star \star}$ & $2.1 \mathrm{~ns}$ & $4.8^{\star \star}$ & $1.4 \mathrm{~ns}$ & $2.9 \mathrm{~ns}$ \\
\hline & 6 & $1.2 \mathrm{~ns}$ & $1.5 \mathrm{~ns}$ & $1.9 \mathrm{~ns}$ & $5.6^{* \star}$ & $8.4^{* \star}$ & $8.3^{* \star}$ & $7.0^{* *}$ & 3.3 * & $23.3^{\text {** }}$ \\
\hline \multirow[t]{2}{*}{ September } & 3 & $0.5 \mathrm{~ns}$ & $0.3 \mathrm{~ns}$ & $0.4 \mathrm{~ns}$ & $9.4^{\star \star}$ & 6.9 ** & $2.5 \mathrm{~ns}$ & $2.0 \mathrm{~ns}$ & $1.7 \mathrm{~ns}$ & $5.1^{*}$ \\
\hline & 6 & $1.2 \mathrm{~ns}$ & $1.1 \mathrm{~ns}$ & $1.5 \mathrm{~ns}$ & $4.7^{*}$ & $19.1^{* *}$ & 27.0 ** & 5.9 ** & $5.9^{* *}$ & $22.0^{* *}$ \\
\hline \multirow[t]{2}{*}{ October } & 3 & $0.8 \mathrm{~ns}$ & $0.8 \mathrm{~ns}$ & $1.6 \mathrm{~ns}$ & 4.9 * & $4.1^{*}$ & $0.3 \mathrm{~ns}$ & $0.8 \mathrm{~ns}$ & $1.1 \mathrm{~ns}$ & 5.6 ** \\
\hline & 6 & $0.6 \mathrm{~ns}$ & $2.3 \mathrm{~ns}$ & $1.9 \mathrm{~ns}$ & $6.4^{\star \star}$ & $9.8^{* *}$ & $14.3^{\text {** }}$ & $5.6^{\star \star}$ & $8.1^{\star *}$ & $14.9^{* *}$ \\
\hline \multirow[t]{2}{*}{ November } & 3 & $0.8 \mathrm{~ns}$ & $0.2 \mathrm{~ns}$ & $2.7 \mathrm{~ns}$ & $9.5^{\star \star}$ & $2.3 \mathrm{~ns}$ & $2.0 \mathrm{~ns}$ & $3.0 \mathrm{~ns}$ & $3.0 \mathrm{~ns}$ & $7.8^{* \star}$ \\
\hline & 6 & $1.2 \mathrm{~ns}$ & $0.4 \mathrm{~ns}$ & $2.6 \mathrm{~ns}$ & $4.7^{\star \star}$ & $12.8^{* *}$ & $7.1^{\star \star}$ & $15.3^{\text {** }}$ & $7.7^{\text {** }}$ & $8.6^{* *}$ \\
\hline \multirow[t]{2}{*}{ December } & 3 & $0.9 \mathrm{~ns}$ & $0.2 \mathrm{~ns}$ & $0.7 \mathrm{~ns}$ & $4.4^{*}$ & $3.5^{*}$ & $1.4 \mathrm{~ns}$ & $0.6 \mathrm{~ns}$ & $4.2^{*}$ & $4.6^{*}$ \\
\hline & 6 & $1.2 \mathrm{~ns}$ & $1.0 \mathrm{~ns}$ & $0.7 \mathrm{~ns}$ & $19.1^{\text {** }}$ & $9.2^{\star \star}$ & $7.7^{\star \star}$ & $8.8^{* *}$ & $41.4^{\star \star}$ & $14.4^{\text {**}}$ \\
\hline
\end{tabular}

F-test: significant at $p<0.05\left(^{*}\right)$ and $p<0.01\left(^{\star *}\right)$; ns: non-significant.

similar result was obtained for $\mathrm{Mg}$, whose coefficients of determination were also higher for samples obtained from the sixth leaf, except if sampling was done in May and September.

In the sixth leaf, variation in mean Ca content for the months of August, September and October was (7 to 11$) \mathrm{g} \cdot \mathrm{kg}^{-1}$, (11 to 16$)$ $\mathrm{g} \cdot \mathrm{kg}^{-1}$ and (7 to 9) $\mathrm{g} \cdot \mathrm{kg}^{-1}$, respectively, and variation in mean $\mathrm{Mg}$ was (3 to 6) $\mathrm{g} \cdot \mathrm{kg}^{-1}$, (7 to 9) $\mathrm{g} \cdot \mathrm{kg}^{-1}$ and (3 to 5) $\mathrm{g} \cdot \mathrm{kg}^{-1}$, respectively (table IV). In other Brazilian carambola orchards, Ca and $\mathrm{Mg}$ contents were reported

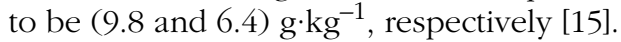
A comparison of the present results with those reported in the literature is severely limited since there are no assays or indications of adequate leaf content of nutrients for the carambola tree. Available reports concern the chemical composition of the leaves under commercial cultivation conditions, but without the appropriate calibration experiments. In addition, the available reports concern adult trees.

$\mathrm{Mn}$ and $\mathrm{Zn}$ concentrations suffered a linear and significant decline with lime application, especially in the sample obtained from the sixth leaf (table $V$ ). At practically all sampling dates, the highest $R^{2}$ was observed if the sixth leaf was used for both Mn and $\mathrm{Zn}$, again indicating that the sixth leaf may represent the nutritional status of the carambola tree.

In the case of $\mathrm{Cu}$ and $\mathrm{Fe}$ concentration, liming also caused a linear decrease in the leaf concentration of these nutrients, except when leaves were sampled in April 2002 when none of the leaves showed a significant change (table VI). No change in Cu content was observed in any of the leaves sampled in April, July and November. In addition, Fe content did not suffer alterations during 


\section{Table IV.}

Linear regressions between lime application ( $\left.\mathrm{t} \cdot \mathrm{ha} \mathrm{C}^{-1}\right)$ and Ca and $\mathrm{Mg}$ contents $\left(\mathrm{g} \cdot \mathrm{kg}^{-1} \mathrm{dry}\right.$ weight) in samples obtained from the third and sixth leaves of carambola branches during different sampling dates in $2002(n=20)$.

\begin{tabular}{|c|c|c|c|}
\hline \multirow{2}{*}{$\begin{array}{l}\text { Sampling } \\
\text { period }\end{array}$} & \multicolumn{2}{|r|}{$\mathrm{Ca}$} & $\mathrm{Mg}$ \\
\hline & Leaf 3 & Leaf 6 & Leaf 6 \\
\hline March & $y=4.90+0.268 \times R 2=0.53 \mathrm{~ns}$ & $y=7.28+0.3759 \times R^{2}=0.96$ ** & $y=2.57+0.128 x R^{2}=0.66^{\star *} \quad y=3.15+0.135 x \quad R^{2}=0.87^{* *}$ \\
\hline April & $y=4.98+0.308 x \quad R^{2}=0.95^{* *}$ & $y=7.28+0.376 \times R^{2}=0.96$ ** & $y=2.75+0.165 \times R^{2}=0.96{ }^{* \star} y=3.28+0.208 \times R^{2}=0.99^{* *}$ \\
\hline May & $y=5.75+0.349 x \quad R^{2}=0.84^{* *}$ & $y=6.82+0.519 \times R^{2}=0.83^{* *}$ & $y=3.52+0.188 \times R^{2}=0.94^{* \star} y=3.47+0.244 \times R^{2}=0.86^{* *}$ \\
\hline June & $y=6.48+0.370 x \quad R^{2}=0.90^{* *}$ & $y=7.17+0.457 \times R^{2}=0.98^{\star \star}$ & $y=3.75+0.231 \times R^{2}=0.87^{* \star} y=3.28+0.231 \times R^{2}=0.89$ ** \\
\hline July & $y=6.57+0.266 x R^{2}=0.81^{* \star}$ & $y=6.63+0.368 \times R^{2}=0.89^{\star \star}$ & $y=3.49+0.245 \times R^{2}=0.98^{\star *} y=3.14+0.305 \times R^{2}=0.98^{* *}$ \\
\hline August & $y=6.75+0.543 x \quad R^{2}=0.86^{* *}$ & $y=7.31+0.4954 \times R^{2}=0.87^{\star *}$ & $y=3.31+0.350 \times R^{2}=0.89^{\star \star} \quad y=3.38+0.269 \times R^{2}=0.96^{* *}$ \\
\hline September & $y=10.27+0.372 \times R^{2}=0.34$ ** & $y=11.46+0.641 \times R^{2}=0.83^{\star \star}$ & $y=7.34+0.336 \times R^{2}=0.90$ ** $y=6.89+0.392 \times R^{2}=0.81^{* *}$ \\
\hline October & $y=3.95+0.543 \times R^{2}=0.85^{* *}$ & $y=2.88+0.153 \times R^{2}=0.90^{\star *}$ & $y=6.48+0.596 \times R^{2}=0.95^{\star \star} \quad y=2.99+0.289 \times R^{2}=0.98^{* *}$ \\
\hline November & $y=3.23+0.241 x R^{2}=0.99$ ** & $y=5.22+0.364 \times R^{2}=0.98^{\star \star}$ & $y=2.80+0.092 \times R^{2}=0.90 \mathrm{~ns} y=3.13+0.164 \times R^{2}=0.80^{* *}$ \\
\hline December & $y=4.22+0.335 x \quad R^{2}=0.92 * *$ & $y=5.81+0.444 \times R^{2}=0.99 * \star$ & $y=2.64+0.148 \times R^{2}=0.94^{* \star} y=3.36+0.212 \times R^{2}=0.99^{* *}$ \\
\hline
\end{tabular}

\section{Table V.}

Linear regressions between lime application ( $\mathrm{t} \cdot \mathrm{ha} \mathrm{a}^{-1}$ ) and $\mathrm{Mn}$ and $\mathrm{Zn}$ contents ( $\mathrm{mg} \cdot \mathrm{kg}^{-1}$ dry weight) in samples obtained from the third and sixth leaves of carambola branches during different sampling dates in $2002(n=20)$.

\begin{tabular}{|c|c|c|}
\hline \multirow{2}{*}{$\begin{array}{l}\text { Sampling } \\
\text { period }\end{array}$} & $\mathrm{Mn}$ & $\mathrm{Zn}$ \\
\hline & Leaf 3 & Leaf 3 \\
\hline March & $y=836.477-26.072 \times R^{2}=0.60 \mathrm{~ns} y=1299.00-48.575 \times R^{2}=0.75$ ** & $y=41.14-1.511 \times R^{2}=0.83^{* *} y=40.92-2.614 \times R^{2}=0.88$ ** \\
\hline April & $y=735.11-35.896 \times \quad R^{2}=0.95^{* *} \quad y=1156.76-55.014 \times R^{2}=0.98^{* *}$ & $y=37.99-1.450 \times R^{2}=0.89^{* *} y=34.56-1.978 \times R^{2}=0.90^{* *}$ \\
\hline May & $y=1168.34-42.542 \times R^{2}=0.88^{* *} y=1449.00-55.209 \times R^{2}=0.87^{\star *}$ & $y=31.34-1.194 \times R^{2}=0.77 \mathrm{~ns} y=28.45-1.423 \times R^{2}=0.78$ * \\
\hline June & $y=1125.78-35.138 \times R^{2}=0.61^{* *} y=1128.20-43.383 \times R^{2}=0.77^{* *}$ & $y=30.66-1.709 \times R^{2}=0.77^{* *} y=28.75-1.815 \times R^{2}=0.92$ ** \\
\hline July & $y=1115.16-9.447 \times R^{2}=0.28 \mathrm{~ns} y=1329.87-56.521 \times R^{2}=0.93^{* *}$ & $y=26.64-0.977 \times R^{2}=0.55$ ns $y=26.19-1.344 \times R^{2}=0.86$ ** \\
\hline August & $y=1375.00-56.258 \times R^{2}=0.51$ ns $y=1639.39-76.407 \times R^{2}=0.83$ ** & $y=34.86-1.383 \times R^{2}=0.48 \mathrm{~ns} y=36.12-2.235 \times R^{2}=0.97^{\text {** }}$ \\
\hline September & $y=1570.15-54.217 \times R^{2}=0.87$ ns $y=1767.12-77.154 \times R^{2}=0.97$ ** & $y=33.33-2.118 \times R^{2}=0.63^{* *} y=31.95-3.223 \times R^{2}=0.95^{* *}$ \\
\hline October & $y=62.83-1,566 x \quad R^{2}=0.35 \mathrm{~ns} \quad y=108.67-4.048 x \quad R^{2}=0.94$ ** & $y=45.58-2.910 \times R^{2}=0.90$ ** $y=34.47-2.222 \times R^{2}=0.97$ ** \\
\hline November & $y=482.87-20.251 x \quad R^{2}=0.87 \mathrm{~ns} \quad y=791.43-40.149 \times R^{2}=0.98$ ** & $y=53.18-2.519 \times R^{2}=0.92^{* *} y=47.55-2.808 \times R^{2}=0.98$ ** \\
\hline December & $y=685.55-21.642 x \quad R^{2}=0.90$ ** $y=1010.59-53.220 \times R^{2}=0.98$ ** & $y=43.10-2.002 \times R^{2}=0.88^{* *} y=40.90-2.740 \times R^{2}=0.99$ ** \\
\hline
\end{tabular}


Table VI.

Linear regressions between lime application $\left(\mathrm{t} \cdot \mathrm{ha}^{-1}\right)$ and $\mathrm{Cu}$ and Fe contents ( $\mathrm{mg} \cdot \mathrm{kg}^{-1}$ dry weight) in samples obtained from the third and sixth leaves of carambola branches during different sampling dates in $2002(n=20)$.

\begin{tabular}{|c|c|c|c|c|}
\hline \multirow{2}{*}{$\begin{array}{l}\text { Sampling } \\
\text { period }\end{array}$} & \multicolumn{2}{|r|}{$\mathrm{Cu}$} & \multicolumn{2}{|c|}{$\mathrm{Fe}$} \\
\hline & Leaf 3 & Leaf 6 & Leaf 3 & Leaf 6 \\
\hline March & $y=4.99-0.106 x \quad R^{2}=0.32 \mathrm{~ns}$ & $y=4.70-0.250 x \quad R^{2}=0.42$ ** & $y=33.40+1.228 x \quad R^{2}=0.61 \mathrm{~ns}$ & $y=44.66-0.575 \times R^{2}=0.25 \mathrm{~ns}$ \\
\hline April & $y=12.11-0.411 \times R^{2}=0.62 \mathrm{~ns}$ & $y=8.50-0.081 \times R^{2}=0.75 \mathrm{~ns}$ & $y=45.69-0.332 \times \quad R^{2}=0.19 \mathrm{~ns}$ & $y=52.84-0.602 \times R^{2}=0.40 \mathrm{~ns}$ \\
\hline May & $y=11.43-0.963 \times R^{2}=0.63^{* *}$ & $y=3.47-0.244 x \quad R^{2}=0.88^{\star \star}$ & $y=60.45-0.552 x \quad R^{2}=0.16 \mathrm{~ns}$ & $y=66.03-0.425 \times R^{2}=0.37 \mathrm{~ns}$ \\
\hline June & $y=7.45-0.216 x \quad R^{2}=0.77^{* \star}$ & $y=8.95-0.404 x \quad R^{2}=0.97^{* *}$ & $y=69.29-0.253 x \quad R^{2}=0.19 \mathrm{~ns}$ & $y=72.72-0.220 \times R^{2}=0.14 \mathrm{~ns}$ \\
\hline July & $y=4.46-0.042 x \quad R^{2}=0.09 \mathrm{~ns}$ & $y=3.95-0.041 x \quad R^{2}=0.33 \mathrm{~ns}$ & $y=88.59-0.185 x \quad R^{2}=0.01^{n s}$ & $y=108.30-3.774 \times R^{2}=0.94$ ** \\
\hline August & $y=5.36-0.121 x \quad R^{2}=0,27 \mathrm{~ns}$ & $y=5.10-0.176 x \quad R^{2}=0.90$ ** & $y=111.30-3.300 x \quad R^{2}=0.78^{*}$ & $y=108.29-3.907 \times R^{2}=0.97^{* *}$ \\
\hline September & $y=2.54-0.107 x \quad R^{2}=0.87 \mathrm{~ns}$ & $y=2.75-0.2443 \times R^{2}=0.76$ ** & $y=288.81-5.737 \times R^{2}=0.38 \mathrm{~ns}$ & $y=307.58-9.613 \times R^{2}=0.96$ ** \\
\hline October & $y=3.35-0.027 x \quad R^{2}=0.20 \mathrm{~ns}$ & $y=4.25-0.351 x \quad R^{2}=0.97^{* *}$ & $y=154.34+2.610 \times R^{2}=0.40 \mathrm{~ns}$ & $y=243.80-6.557 \times R^{2}=0.57^{* *}$ \\
\hline November & $y=8,31-9.557 x \quad R^{2}=0.39 \mathrm{~ns}$ & $y=6.96-0.0217 \times R^{2}=0.88^{* *}$ & $y=61.53-0.611 x \quad R^{2}=0.09 \mathrm{~ns}$ & $y=78.29-3.01 x \quad R^{2}=0.93$ ** \\
\hline December & $y=7.0-0.149 x \quad R^{2}=0.82 \mathrm{~ns}$ & $y=6.56-0.2571 \times R^{2}=0.93^{* *}$ & $y=55.96-0.620 x \quad R^{2}=0.25 \mathrm{~ns}$ & $y=99.10-5.034 \times R^{2}=0.97$ ** \\
\hline
\end{tabular}

the first five leaf samplings. Whenever there were changes in Fe and Cu leaf concentrations, the coefficient of determination was always higher for the sixth leaf than for the third leaf.

The reduced leaf concentrations of $\mathrm{Cu}$, $\mathrm{Fe}, \mathrm{Mn}$ and $\mathrm{Zn}$ were due to the decreased availability of these metals in soil due to liming which promotes an elevation in $\mathrm{pH}$ [14].

Our results showed the advantage of the sixth leaf over the third leaf in the determination of the effect of liming on the leaf nutritional status of carambola trees. These results are in agreement with data reported in the literature demonstrating that each leaf type generally presents a distinct composition and sensitivity to the detection of nutrients available in the soil [6].

The analysis of the different sampling periods showed that liming had a significant effect on macro- and micronutrient levels between August and October, triggering increases in $\mathrm{Ca}$ and $\mathrm{Mg}$ contents and decreases in $\mathrm{Mn}, \mathrm{Zn}, \mathrm{Cu}$ and Fe contents. This fact was possibly due to the high physiological activity of the plant (flowering peak) during this period [4]. Indeed, peaks in the concentration of most nutrients in tissues occur at flowering time [16, 17]. Thus, this period can be considered the most adequate for leaf sampling and analysis, discriminating alterations in chemical soil attributes with a higher precision. Therefore, we suggest that, in tropical areas, the months from August to October could be the most adequate for leaf diagnosis in irrigated carambola trees. It should be noted that during this period the plant is in full bloom which is accompanied by high physiological activity; however, the choice of the collection month should be compatible with the flowering peak, which might suffer alterations according to the edaphoclimatic conditions of the region and the cultivar used. Sampling performed during this period permits the highest precision in the fertilization options after this period (November to March) by adjusting more or less the fertilizer doses.

\section{Conclusion}

For leaf diagnosis of irrigated carambola trees in tropical regions similar to those of the state of São Paulo, Brazil, the sixth leaf formed on flowering branches is the most indicated to be collected. Selected branches will have to be without fruit, located in the 
plant's middle third and sampled at the flowering peak during the months of August to October.

\section{Acknowledgements}

The authors wish to thank the FAPESP (Fundação de Amparo à Pesquisa do Estado de São Paulo), for financial support.

\section{References}

[1] Lennox A., Ragoonath J., Carambola and bilimbi, Fruits 45 (1990) 497-508.

[2] Donadio L.C., Carambola growing in Brazil, Proc. Inter. Soc. Trop. Hortic. 33 (1989) 26-29.

[3] Baligar V.C., Ahlrichs J.L., Nature and distribution of acid soils in the world, in: Schaffert R.E. (Ed.), Proc. Workshop "Develop a strategy for collaborative research and dissemination of technology in sustainable crop production in acid savannas and other problem soils of the world", Purdue University, West Lafayette, 1998, pp. 1-11.

[4] Donadio L.C., Silva J.A.A., Araújo P.R.S. Prado R.M., Caramboleira (Averrhoa carambola L.), Soc. Bras. Frutic., Jaboticabal, Brasil, 2001.

[5] Smith P.F., Leaf analysis of citrus, in: Childers N.F. (Ed.), Nutrition of fruit crops, Hortic. Publ. Rutgers, New Jersey, USA, 1966, pp. 208228.

[6] Jones Jr. J.B., Wolf B., Mills H.A., Plant analysis handbook: a practical sampling, preparation, analysis, and interpretation guide, Micro-Macro Publ., Athens, USA, 1991.

[7] Malavolta E., ABC da análise de solos e folhas: amostragem, interpretação e sugestões de adubação, Agronômica Ceres, São Paulo, Brasil, 1992.

[8] Crane J.H., Tropical fruits, cd-rom, Inst. Food Agric. Sci., Univ. Fla, USA, 1998.

[9] Monselise S.P., Heymann-Herschberg L., Influence of exposure and age on dry matter content are an mineral composition of shamouti orange leaves, Proc. Am. Soc. Hortic. Sci. 62 (1953) 67-73.

[10] Gowda V.N., Srivastava K.C., Gowda J.V.N., Studies on the nutrient status of Coorg mandarin (Citrus reticulata L.) leaves as influenced by zone of leaf sampling on the tree, Haryana J. Hortic. Sci. 14 (1985) 16-19.

[11] Bataglia O.C., Furlani A.M.C., Teixeira J.P.F., Furlani P.R., Gallo J.R., Métodos de análise química de plantas, Inst. Agron., Campinas, Brasil, Bol. Téc. 78, 1983.

[12] Anonymous, SAS User's guide: statistics, 5th ed., SAS Institute, Cary, N.C., USA, 1985.

[13] Quaggio J.A., Dechen A.R., Raij B. Van, Efeitos da aplicação de calcário e gesso sobre a produção de amendoim e lixiviação de bases no solo Campinas, Rev. Bras. Ciênc. Solo 6 (1982) 189-194.

[14] Malavolta E., Manual de química agrícola: adubos e adubação, Agron. Ceres, São Paulo, Brasil, 1981.

[15] Silva H., Silva A.Q., Cavalcanti A.T., Malavolta E., Composição mineral das folhas de algumas fruteiras do Nordeste, in: Congr. Bras. Frutic., 7, EMPASC/SBF, Florianópolis, Brasil, 1984, Vol. 1, pp. 320-325.

[16] Kenworthy A.L., Interpreting the balance of nutrient elements in leaves of fruit trees, in: Plant analysis and fertilizers problems, 3 , East Leasing, 1961, pp. 28-43.

[17] Christensen L.P., Kasimatis A.N., Jensen F.L., Grapevine nutrition and fertilization in San Joaquin Valley, Univ. California, Berkeley, USA, 1982, $40 \mathrm{p}$ 


\section{Muestreo foliar en el carambolero.}

Resumen - Introducción. La falta de información en la literatura sobre el momento más adecuado para el muestreo foliar y la hoja más indicada para la evaluación del estado nutricional del carambolero limita la utilización del análisis foliar como técnica de diagnóstico para esta especie. Por ello, estudiamos las variaciones estacionales de la composición mineral de hojas de caramboleros cultivados en un suelo ácido y sometidos a la aplicación de cal para definir criterios que permitan elegir las hojas utilizables para un diagnóstico nutricional del árbol así como el período apto para este estudio. Material y métodos. El experimento se estableció en un suelo fersialítico típico en Bebedouro, São Paulo, Brasil, con dosis de cal de $\left(0,1,85,3,79,5,56\right.$ y 7,41) $\mathrm{t} \cdot \mathrm{ha}^{-1}$ aplicadas en agosto de 1999. Unos caramboleros jóvenes injertados (cv. Malaisie) fueron plantados en diciembre de 1999. Para evaluar el estado nutricional de las plantas, se determinaron las concentraciones foliares de micro y macroelementos en la tercera y sexta hoja, incluido el peciolo, de ramas en floración pero sin frutos, localizadas en el tercio medio del árbol. Se tomaron muestras de hojas durante todo el año 2002, excepto en enero y febrero por la ausencia de flores. Resultados y discusión. Los resultados pusieron de manifiesto que la sexta hoja era más eficaz que la tercera para evaluar el estado nutricional de los caramboleros; el encalado indujo efectos significativos en el contenido de $\mathrm{Ca}, \mathrm{Mg}, \mathrm{Mn}, \mathrm{Zn}$, Cu y Fe, sobre todo en los muestreos efectuados de agosto a octubre. Conclusión. En la zona afectada por este estudio, la sexta hoja, tomada durante el pico de floración entre agosto y octubre, parece apta para permitir un diagnóstico alimenticio del carambolero.

Brasil / Averrboa carambola / estado nutricional diagnóstico / métodos / hojas / contenido mineral / muestra

To access this journal online: www.edpsciences.org 